(C) 2014

\author{
Цилюрик О. І., кандидат сільськогосподарських наук, \\ Шапка В. П., аспірант
}

(науковий керівник - кандидат сільськогосподарських наук О. І. Цилюрик) ДУ Інститут сільського господарства степової зони НААН України

\title{
ЕФЕКТИВНІСТЬ БЕЗПОЛИЦЕВОГО ОБРОБІТКУ ІРУНТУ ЗА ВИРОЩУВАННЯ ЯЧМЕНЮ ЯРОГО В ПІВНІЧНОМУ СТЕПУ
}

\section{Рецензент - доктор сільськогосподарських наук, академік НААН С. М. Лебідь}

\begin{abstract}
Вивчено вплив різних способів основного обробітку трунту під ячмінь ярий на агрофізичні властивості, водний режим чорнозему звичайного, забур'яненість посівів, продуктивність і економічну ефективність виробництва зернової культури. Встановлено, щчо чизельний обробіток трунту в умовах посушливого північного Cmепу Украӥни забезпечує зростання акумуляції трунтової вологи в осінньо-зимовий період завдяки наявності на поверхні трунту рослинних залишків попередника $і$ хвилястому нанорельєфу. Це гарантує максимальні запаси продуктивної вологи навесні порівняно з іншими способами основного обробітку трунту, а також високий урожай $і$ найвищчий рівень рентабельності виробництва зерна. Використання мілкого дискового обробітку трунту (10-12 см) під ячмінь ярий призводить до підвищення забур'яненості посівів, щуо є однією з причин зниження урожайності зернофуражної культури на 0,20-0,46 m/2а по відноченню до полицевої оранки та чизелювання.
\end{abstract}

Ключові слова: ячмінь ярий, основний обробіток трунту, агрофізичні властивості, продуктивна волога, мінеральні добрива, урожай.

Постановка проблеми. У зв'язку зі зміною пріоритетів розвитку степового землеробства, пов'язаних iз подорожчанням енергетичних i матеріальних ресурсів, зміною кліматичних умов степової зони, частим розміщенням ячменю ярого після нетипового попередника соняшника внаслідок розширенням його площ посівів (понад 5 млн га) за останні роки, а також застосування полицевої оранки у вирощуванні зернової культури, супроводжується посиленням ерозійних процесів, надмірним техногенним навантаженням, погіршенням водного режиму та гумусного стану чорноземів.

Перелічені вище негативні чинники обумовлюють необхідність удосконалення системи основного обробітку грунту під ячмінь ярий у напрямі його мінімалізації, з урахуванням грунтово-кліматичних умов, кількості залишених післяжнивних решток попередника, добрив, фітосанітарного стану посівів [3, 4, 8, 9].
Аналіз останніх досліджень і публікацій, у яких започатковано розв'язання проблеми. Ячмінь ярий потребує порівняно високих вимог до фізичного стану грунту, вмісту в ньому рухомих легкодоступних поживних речовин і достатньої кількості вологи, які, як відомо, регулюється способами обробітку грунту та їх глибиною, а також внесенням оптимальних доз мінеральних добрив [2, 10].

На думку більшості дослідників, найкращим способом обробітку грунту під ячмінь ярий $\epsilon$ осінній полицевий обробіток із попереднім лущенням стерні, застосування якого дає суттєві прибавки зерна порівняно з іншими способами обробітку грунту, особливо в посушливі роки. У разі заміни зяблевої оранки осіннім дискуванням основна маса коренів рослин ячменю розміщується мілкіше, ніж по зябу. Це ставить рослини у залежність від літніх опадів, що загрожує їх продуктивності. Так, наприклад, на Генічеській, Розівській і Запорізькій дослідних станціях від заміни оранки після кукурудзи на зерно дискуванням урожай зерна ячменю в середньому за три роки зменшився на $0,22-0,32$ т/га, а на Драбівській дослідній станції після цукрових буряків у середньому за 6 років після дискування урожай був меншим на 0,21 т/га ніж після оранки. За узагальненими даними дослідів, поверхневий обробіток під ячмінь ярий здебільшого поступається урожаєм перед оранкою [2].

В останні десятиріччя із загальною тенденцію до мінімалізації обробітку грунту В. Ф. Сайко та А. М. Малієнко пропонують обробіток під ячмінь ярий після просапних попередників диференціювати, тобто оранку доцільніше застосовувати у сприятливі за вологістю роки, а поверхневий обробіток - у посушливі [11]. Такої ж думки дотримуються й А. П. Коваленко [5], М. А. Білоножко [1] та А. А. Конищев [6], які надають перевагу мілкому обробітку, але не тільки після просапних (кукурудзи та соняшнику), а й стерньових культур (пшениця озима). 


\section{СІЛЬСЬКЕ ГОСПОДАРСТВО. РОСЛИННИЦТВО}

Враховуючи суперечливість поглядів різних вчених стосовно доцільності того чи іншого способу обробітку грунту під ячмінь ярий на фоні загальної неоднорідності грунтового покриву, зміни кліматичних умов та прояву ерозійних процесів, на нашу думку, й надалі залишатиметься актуальним питання вивчення ефективності способів основного обробітку грунту під ячмінь ярий у північному Степу.

Мета і завдання досліджень. Головна мета даної роботи - встановити вплив різних способів основного обробітку грунту і внесених мінеральних добрив (у разі залишення післяжнивних решток попередника) на агрофізичні властивості грунту, водний режим, забур'яненість, продуктивність i економічну ефективність вирощування ячменю ярого в умовах північного Степу України.

Для досягнення поставленої мети необхідно було вирішити такі завдання:

- дослідити зміни основних параметрів агрофізичного стану чорноземів (структура, щільність, твердість) на фоні полицевого (оранка) та безполицевого (чизельний, дисковий) обробітків грунту 3 метою виявлення кращих способів та удосконалення механізмів самовідновлення грунту;

- вивчити закономірності формування водного режиму грунту за застосування різних способів обробітку грунту з метою створення оптимальних умов вологозабезпечення рослин;

- виявити вплив способів обробітку грунту й мінерального удобрення 3 використанням рослинних решток на забур'яненість посівів та урожайність ячменю ярого;

- оцінити економічну ефективність досліджуваних способів основного обробітку грунту й удобрення ячменю ярого для розробки пропозицій аграрному виробництву.

Матеріали і методи досліджень. Експериментальні дослідження виконували протягом 2011-2013 pр. у стаціонарному польовому досліді ДУ Інститут сільського господарства степової зони НААН України у п'ятипільній короткоротаційній сівозміні: чистий пар - пшениця озима - соняшник - ячмінь ярий - кукурудза 3 загальнофоновим залишенням післяжнивних решток усіх польових культур. Основний обробіток грунту під ячмінь ярий проводили полицевим плугом ПО-3-35 на глибину 20-22 см (контроль), безполицевий (чизельний) обробіток - канадським чизель-культиватором Conser Till Plow на 14-16 см, безполицевий (дисковий) обробіток грунту - важкими дисковими боронами БДВ-3 на 10-12 см. Висівали сорт ячменю ярого Ілот, що адаптований до посушливих умов Степу. Посіви обов'язково обробляли в фазу кущіння гер- біцидом естерон - 0,8 л/га для повного знищення падалиці соняшнику і бур'янів. Схема досліду також включала три фони удобрення: 1) без добрив + післяжнивні рештки попередника; 2) $\mathrm{N}_{30} \mathrm{P}_{30} \mathrm{~K}_{30}+$ післяжнивні рештки попередника; 3) $\mathrm{N}_{60} \mathrm{P}_{30} \mathrm{~K}_{30}+$ післяжнивні рештки попередника. Мінеральні добрива вносили навесні розкидним способом під передпосівну культивацію. Всі експериментальні дослідження проводили у відповідності до загальноприйнятих методик. Дослід закладений у трьохкратній повторності, загальна площа посівної ділянки - 330 м², облікової $-100 \mathrm{~m}^{2}$.

Грунт дослідної ділянки - чорнозем звичайний важкосуглинковий із умістом гумусу в шарі 0-30 см - 4,2 \%, нітратного азоту - 13,2, рухомих форм фосфору і калію (за Чириковим) 145 і 115 мг/кг відповідно.

Несприятливі метеорологічні умови для вирощування ячменю ярого складалися в 2012 та 2013 роках. Гідротермічний коефіцієнт (ГТК) у період найбільшого водоспоживання рослинами зернової культури (травень - перша половина червня) складав у 2011 р. - 0,8, у 2012 р. - 0,6 і в 2013 p. 0,7. Показники ГТК менше 0,7 свідчать про наявність грунтово-повітряної посухи, що негативно впливала на формування й налив зерна.

Результати досліджень. Як показали результати досліджень, агрофізичні показники грунту незалежно від способів його обробітку - знаходилися в оптимальних параметрах. Щільність будови грунту (об’ємна маса) не перевищувала

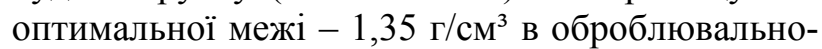
му шарі й складала по полицевій оранці - 1,18, чизелюванні - 1,25, дисковому обробітку 1,26 г/см³. Слід зауважити, що за мілкого дискового обробітку спостерігалася диференціація оброблювального шару за показниками щільнос-

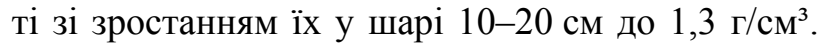
Це, безумовно, пов'язано з механізмом дії робочих органів (диски) грунтообробного знаряддя (БДВ-3) на поверхню грунту, внаслідок чого ущільнюється нижчележачий від верхнього необроблений шар грунту (10-20 см). Твердість грунту в разі полицевої оранки в шарі 0-30 см

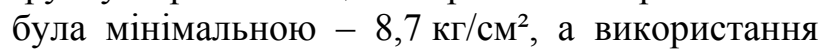
чизельних та дискових знарядь сприяло зростан-

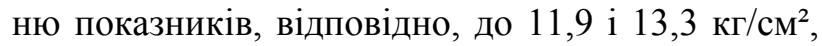
не перевищуючи оптимальних параметрів (до

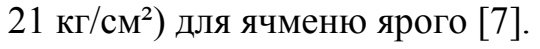

Структурний аналіз грунту, проведений навесні перед посівом зернової культури, показав, що незалежно від способів обробітку грунту сума агрономічно цінних структурних агрегатів розміром 10-0,25 мм знаходилася в межах 73,2-75,9\%. 


\section{СІЛЬСЬКЕ ГОСПОДАРСТВО. РОСЛИННИЦТВО}

Відмічена тенденція до підвищення найбільш цінних структурних агрегатів розміром 7-0,25 мм на фоні чизельного та дискового обробітків.

Запаси продуктивної вологи в середньому за три роки досліджень навесні у півтораметровому шарі грунту становили по оранці - 151,7, чизелюванні - 169,8, дисковому обробітку - 160,5 мм (табл. 1). Перевага у накопиченні вологи в осінньо-зимовий період на 18,1 мм (181 т/га) відмічена по чизельному обробітку порівняно 3 полицевою оранкою.

Це пояснюється, насамперед, наявністю післяжнивних залишків попередника на поверхні грунту та хвилястим нанорельєфом. У кінцевому підсумку зазначені вище особливості чизелювання сприяли більшому накопиченню снігу на тлі загального недобору нормативної суми опадів протягом грудня-січня та практично відсутності значного снігового покриву в роки проведення досліджень. У подальшому водний режим у посівах ячменю ярого змінювався залежно від стану грунту, росту і розвитку рослин на різних фонах удобрення, гідротермічних умов. У фазу колосіння ячменю ярого грунтові запаси вологи в півтораметровому шарі, порівняно 3 першим визначенням навесні, суттєво зменшувалися по варіантах досвіду до показників 14,9-50,4 мм. Тобто, в цей період, який відзначався недобором атмосферних опадів, рослини більше витрачали грунтову вологу на формування своєї вегетативної маси. Більш розвинені рослини по габітусу на тлі оранки і чизелювання використовували максимальну іiі кількість -115,1-136,8 та 123137,9 мм відповідно, а застосування дискового обробітку знижувало цей показник до 110,0121,5 мм. Внесення мінеральних добрив також сприяло збільшенню вологоспоживання рослинами по висхідній без добрив - $\mathrm{N}_{30} \mathrm{P}_{30} \mathrm{~K}_{30}-$ $\mathrm{N}_{60} \mathrm{P}_{30} \mathrm{~K}_{30}$ (табл. 1).

Забур'яненість посівів, у фазу кущіння, залежно від способів основного обробітку грунту, суттєво змінювалася й становила по оранці в межах фонів удобрення - 9,6-11,2, чизелюванні - 11,2-13,6, дискуванні - 15,2-17,6 шт/м² бур'янів. Найменші кількісні показники за оранки пояснюються заорюванням насіння бур'янів із верхніх шарів у нижні, що, зрештою, ускладнює їх проростання 3 більш глибоких горизонтів. Внесення мінеральних азотних добрив у дозі $\mathrm{N}_{30} \mathrm{P}_{30} \mathrm{~K}_{30}$ i $\mathrm{N}_{60} \mathrm{P}_{30} \mathrm{~K}_{30}$ стимулювало проростання бур'янів, що зумовлювало зростання їх чисельної кількості у фазу кущіння зернової культури в 1,1-1,2 рази, особливо нітрофілов (лобода біла (Chenopodium album L.), щириця загнута (Amarantus retroflexus L.)). На ранніх етапах органогенезу, до внесення гер- біциду «Естерон», за оранки і чизелювання в агроценозі повністю домінувала падалиця соняшнику (44,2-76,7 \%), дисковому обробітку - падалиця соняшнику (48,6-50,5\%) i амброзія полинолиста (45,9-48,7\%). Амброзія полинолиста (Ambrosia artemisiifolia L.) та інші бур'яни легко проростають у місцях, де рослини ячменю ярого менш розвинені й слабо покривають поверхню грунту, тобто менш конкурентоздатні по відношенню до бур'янів, особливо на варіантах дискування. 3 часом (фаза колосіння), внаслідок дії гербіциду «Естерон», а також збільшення габітусу рослин на удобрених варіантах, забур'яненість, навпаки, зменшувалася порівняно 3 неудобреним фоном і становила: 6-18 шт./ ${ }^{2}$

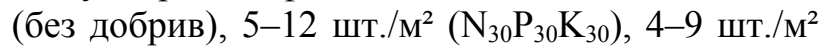
$\left(\mathrm{N}_{60} \mathrm{P}_{30} \mathrm{~K}_{30}\right)$. На оранці їх кількість становила - 4,0-

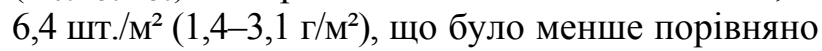
3 чизелюванням за кількістю в 1,6-1,7, а по масі - в 1,2-2,0 рази. Найбільш забур'яненими, як і на початку вегетації були задисковані ділянки $(7,4-$ 8,2 шт./M²).

Показники урожайності ячменю ярого за використання полицевої оранки та чизелювання були майже рівноцінними: 2,51-2,90 та 2,36-2,88 т/га відповідно (табл. 2). Дискування грунту знижувало урожайність зернової культури на 0,2-0,46 т/га. У надто посушливому 2012 році чизельний обробіток за урожайністюі навіть перевищував полицеву оранку на 0,05-0,09 т/га на ділянках із внесенням мінеральних добрив, що, безумовно, пов'язано з кращою вологозабезпеченістю посівів. Основною причиною зниження урожаю ячменю ярого після соняшнику по дисковому обробітку, 3 нашого погляду, $\epsilon$ зростання забур'яненості посівів, особливо збільшення числа амброзії полинолистої (Ambrosia artemisiifolia L.) до 45,9-48,7 \%, а також наявність значної кількості рослинних залишків попередника на поверхні грунту. Більш повне перемішування рослинного субстрату попередника, разом 3 інтенсивним прогріванням верхнього шару в разі оранки і чизелювання навесні, сприяють формуванню кращих вихідних умов для життєдіяльності мікробних популяцій i вилучення іммобілізованих мінеральних поживних речовин (N-NO${ }_{3}, \mathrm{P}_{2} \mathrm{O}_{5}, \mathrm{~K}_{2} \mathrm{O}$ та інших) у грунтовий розчин, що, зрештою, й покращує умови поживного режиму [10]. Використання мілкого дискового обробітку грунту (10-12 см) у технології вирощування ячменю ярого, незважаючи на зниження урожаю зерна, забезпечило, порівняно з оранкою і чизелюванням: економію пального - 13,2-12,0 л/га, зменшення витрат праці на 0,91-0,62 люд.-год./га i коштів на суму 260-191 грн/га відповідно. 
СІЛЬСЬКЕ ГОСПОДАРСТВО. РОСЛИННИЦТВО

\section{1. Запаси продуктивної вологи залежно від способів основного обробітку грунту та внесених мінеральних добрив під ячмінь ярий (иар 0-150 см), мм}

\begin{tabular}{|c|c|c|c|c|c|c|c|c|c|c|c|c|}
\hline \multirow{3}{*}{$\begin{array}{l}\text { Обробіток } \\
\text { грунту }\end{array}$} & \multicolumn{9}{|c|}{ Роки і строки проведення } & \multicolumn{3}{|c|}{ Середнє } \\
\hline & \multicolumn{3}{|c|}{ посів } & \multicolumn{3}{|c|}{ колосіння } & \multicolumn{3}{|c|}{ збирання врожаю } & \multirow{2}{*}{ посів } & \multirow{2}{*}{ колосіння } & \multirow{2}{*}{$\begin{array}{c}\text { збиран- } \\
\text { ня вро- } \\
\text { жаю }\end{array}$} \\
\hline & 2011 & 2012 & 2013 & 2011 & 2012 & 2013 & 2011 & 2012 & 2013 & & & \\
\hline \multicolumn{13}{|c|}{ без добрив } \\
\hline $\begin{array}{c}\text { Полицевий } \\
\text { (оранка) } \\
\text { (20-22 см) }\end{array}$ & 163,1 & 82,1 & 210,0 & 26,5 & 16,5 & 66,8 & 45,2 & 0 & 77,0 & 151,7 & 36,6 & 40,7 \\
\hline $\begin{array}{c}\text { Безполицевий } \\
\text { (чизельний) } \\
(14-16 \text { см) }\end{array}$ & 172,9 & $\begin{array}{c}117, \\
1\end{array}$ & 219,4 & 43,9 & 10,1 & 86,4 & 51,3 & 0 & 118,0 & 169,8 & 46,8 & 56,4 \\
\hline $\begin{array}{c}\text { Безполицевий } \\
\text { (дисковий) } \\
(10-12 \text { см) } \\
\end{array}$ & 174,7 & 98,3 & 208,6 & 60,3 & 16,7 & 74,4 & 60,6 & 0 & 95,8 & 160,5 & 50,4 & 56,4 \\
\hline \multicolumn{13}{|c|}{$\mathrm{N}_{30} \mathrm{P}_{30} \mathrm{~K}_{30}$} \\
\hline $\begin{array}{l}\text { Полицевий } \\
\text { (оранка) } \\
\text { (20-22 см) }\end{array}$ & 163,1 & 82,1 & 210,0 & 13,1 & 10,8 & 49,6 & 48,8 & 0 & 78,0 & 151,7 & 24,5 & 42,2 \\
\hline $\begin{array}{c}\text { Безполицевий } \\
\text { (чизельний) } \\
(14-16 \text { см) }\end{array}$ & 172,9 & $\begin{array}{c}117 \\
1\end{array}$ & 219,4 & 23,2 & 7,2 & 81,4 & 56,2 & 0 & 86,5 & 169,8 & 37,2 & 47,5 \\
\hline $\begin{array}{c}\text { Безполицевий } \\
\text { (дисковий) } \\
(10-12 \text { см) } \\
\end{array}$ & 174,7 & 98,3 & 208,6 & 47,8 & 0,6 & 72,6 & 69,1 & 0 & 94,4 & 160,5 & 40,3 & 54,5 \\
\hline \multicolumn{13}{|c|}{$\mathrm{N}_{60} \mathrm{P}_{30} \mathrm{~K}_{30}$} \\
\hline $\begin{array}{c}\text { Полицевий } \\
\text { (оранка) } \\
\text { (20-22 см) }\end{array}$ & 163,1 & 82,1 & 210,0 & 9,3 & 4,5 & 31,1 & 48,1 & 0 & 52,7 & 151,7 & 14,9 & 33,6 \\
\hline $\begin{array}{c}\text { Безполицевий } \\
\text { (чизельний) } \\
\text { (14-16 см) }\end{array}$ & 172,9 & $\begin{array}{c}117 \\
1\end{array}$ & 219,4 & 20,3 & 0,4 & 75,0 & 58,7 & 0 & 57,1 & 169,8 & 31,9 & 38,6 \\
\hline $\begin{array}{c}\text { Безполицевий } \\
\text { (дисковий) } \\
\text { (10-12 см) }\end{array}$ & 174,7 & 98,3 & 208,6 & 43,3 & 0,3 & 73,6 & 66,9 & 0 & 90,7 & 160,5 & 39,0 & 52,5 \\
\hline
\end{tabular}

За полицевої оранки і чизельного обробітку грунту отримано істотно вищий урожай зерна, ніж за дискування, що сприятливо позначилося на собівартості виробництва зерна та рентабельності його виробництва. Найвищий рівень рентабельності забезпечив чизельний обробіток грунту $(48,7 \%)$, дещо нижчі показники отримано за полицевої оранки $(44,7 \%)$, а мінімальні, безумовно, за дискового обробітку скиби $(41,0 \%)$.

Висновки: 1. Безполицевий (чизельний) обробіток грунту в умовах посушливого північного Степу України забезпечує зростання акумуляції грунтової вологи в осінньо-зимовий період завдяки наявності на поверхні грунту рослинних залишків попередника і хвилястому нанорельефу, що гарантує максимальні запаси продуктивної вологи навесні порівняно 3 іншими способами основного обробітку грунту.

2. Використання мілкого дискового обробітку грунту (10-12 см) під ячмінь ярий призводить до підвищення забур'яненості посівів, особливо амброзією полинолистою (Ambrosia artemisiifolia L.), співвідношення якої зростає до 45,9-48,7 \% від загальної кількості бур'янів, що є однією 3 причин зниження урожайності зернофуражної культури на 0,20-0,46 т/га по відношенню до полицевої оранки та чизелювання.

3. Полицева оранка і чизелювання в умовах північного Степу сприяють формуванню найвищого i практично однакового урожаю зерна ячменю ярого 2,51-2,90 і 2,36-2,88 т/га відповідно, що сприятливо позначається на собівартості основної продукції та рівні рентабельності його виробництва (44,7-48,7 \%). 
СІЛЬСЬКЕ ГОСПОДАРСТВО. РОСЛИННИЦТВО

2. Урожсайність ячменю ярого залежно від способів основного обробітку грунту та удобрення, $\mathrm{m} / 2 а$

\begin{tabular}{|c|c|c|c|c|c|}
\hline \multirow{2}{*}{$\begin{array}{l}\text { Обробіток грунту } \\
\text { (фактор А) }\end{array}$} & \multirow{2}{*}{$\begin{array}{l}\text { Удобрення } \\
\text { (фактор В) }\end{array}$} & \multicolumn{3}{|c|}{ Роки } & \multirow{2}{*}{ Середнє } \\
\hline & & 2011 & 2012 & 2013 & \\
\hline \multirow{3}{*}{$\begin{array}{c}\text { Полицевий (оранка) } \\
\text { (20-22 см) }\end{array}$} & без добрив & 3,66 & 1,55 & 2,33 & 2,51 \\
\hline & $\mathrm{N}_{30} \mathrm{P}_{30} \mathrm{~K}_{30}$ & 3,78 & 1,75 & 2,50 & 2,67 \\
\hline & $\mathrm{N}_{60} \mathrm{P}_{30} \mathrm{~K}_{30}$ & 3,90 & 1,93 & 2,87 & 2,90 \\
\hline \multirow{3}{*}{$\begin{array}{c}\text { Безполицевий (чизельний) } \\
\text { (14-16 см) }\end{array}$} & без добрив & 3,37 & 1,51 & 2,20 & 2,36 \\
\hline & $\mathrm{N}_{30} \mathrm{P}_{30} \mathrm{~K}_{30}$ & 3,69 & 1,80 & 2,39 & 2,62 \\
\hline & $\mathrm{N}_{60} \mathrm{P}_{30} \mathrm{~K}_{30}$ & 3,83 & 2,02 & 2,81 & 2,88 \\
\hline \multirow{3}{*}{$\begin{array}{c}\text { Безполицевий (дисковий) } \\
\text { (10-12 см) }\end{array}$} & без добрив & 2,82 & 1,48 & 1,87 & 2,05 \\
\hline & $\mathrm{N}_{30} \mathrm{P}_{30} \mathrm{~K}_{30}$ & 3,27 & 1,71 & 2,08 & 2,35 \\
\hline & $\mathrm{N}_{60} \mathrm{P}_{30} \mathrm{~K}_{30}$ & 3,56 & 1,90 & 2,59 & 2,68 \\
\hline \multirow{3}{*}{$\mathrm{HIP}_{05}$} & $\mathrm{~A}$ & 0,23 & 0,13 & 0,18 & - \\
\hline & $\mathrm{B}$ & 0,25 & 0,15 & 0,17 & - \\
\hline & $\mathrm{AB}$ & 0,38 & 0,25 & 0,30 & - \\
\hline
\end{tabular}

\section{БІБЛІОГРАФІЯ}

1. Білоножко М. А. Рослинництво. Інтенсивна технологія вирощування польових і кормових культур: Навчальний посібник / М. А. Білоножко, В. П. Шевченко, Д. М. Алімов [та ін.]. - К. : Вища школа, 1990. - 292 с.

2. Борисоник 3. Б. Ярі колосові культури / 3. Б. Борисоник, О. М. Борсук. - К. : Урожай, 1969. - $158 \mathrm{c}$.

3. Горбатенко A. I. Мінімалізація обробітку грунту при вирощуванні ярого ячменю в Степу / А. I. Горбатенко, А. Г. Горобець, О. І. Цилюрик // Агроном. - 2009. - №4 (26). - С. 40-45.

4. Гордієнко В. П. Вплив тривалого застосування різних систем удобрення й обробітку грунту в сівозміні на урожайність ярого ячменю / В. П. Гордієнко, В. І. Бодня // Наукові праці Полтавської державної аграрної академії. - Полтава, 2005. - T. 4 (23). - C. 94-100.

5. Коваленко А. П. Интенсификация производства зерна / А. П. Коваленко // Земледелие. 1972. - № 9. - С. 11-12.
6. Конищев А. А. Погодные условия и выбор обработки почвы / А. А. Конищев, Е. Н. Конищева // Земледелие. - 2007. - № 6. - С. 12.

7. Мєдвєдєв $B$. $B$. Нульовий обробіток грунту в європейських країнах / В.В.Мєдвєдєв. - Х. : ТОВ «Едена», 2010. - 202 с.

8. Пабат I. А. Мінімалізація обробітку грунту при вирощуванні сільськогосподарських культур / I. А. Пабат, М. С. Шевченко, А. І. Горбатенко // Вісник аграрної науки. - 2004. - №1. - С. 11-14.

9. Пабат I. А. Попередники, добрива і обробіток грунту під ярий ячмінь у Степу / I. А. Пабат, А. Г. Горобець, А. І. Горбатенко // Вісник аграрної науки. - 2002. - №4. - С. 17-21.

10. Сайко В. Ф. Системи обробітку грунту в Україні / Сайко В. Ф., Малієнко А. М. - К. : ВД «ЕМКО», 2007. - $44 \mathrm{c}$.

11. Сокол А. А. Ячменное поле Дона: опыт возделывания и рекомендации / А. А. Сокол. Ростов-на-Дону : Ростовское книжное издательство, 1985. - 112 с. 